\title{
Black Sagebrush: Mule Deer Winter Preference and Monoterpenoid Content
}

\author{
BARBARA BEHAN AND BRUCE L. WELCH
}

\begin{abstract}
Wintering mule deer (Odocoileus hemionus hemionus) preference was determined for 7 accessions of black sagebrush (Artemisia nova) grown on a common garden. Preference as expressed as percentage of current annual growth eaten varied from 0.0 to 82.7\%. An accession called Pine Valley Ridge was significantly preferred by the deer over the other 6 accessions. We also attempted to relate monoterpenoid content to preference. We found no significant relationship between the two.
\end{abstract}

Contradictory observations have been reported concerning the preference wintering mule deer (Odocoileus hemionus hemionus) have for black sagebrush (Artemisia nova). Nagy and Regelin (1977) reported that black sagebrush was generally preferred by mule deer over big sagebrush (Artemisia tridentata). However, Smith (1950) and Sheehy and Winward (1981) reported that wintering mule deer preferred some sagebrush taxa over others, with black sagebrush the least preferred. These contradictory observations are probably due, in part, to genetic differences among the black sagebrush used in the studies. We have observed over the past 7 years differential preference on the part of wintering mule deer for accessions of black sagebrush growing on our uniform garden (Stevens and McArthur 1974, Welch et al. 1981). These observations support the contention that genetic differences do exist. One genetic factor that has been reported as influencing mule deer preference is composition of monoterpenoids in the forage (Nagy and Regelin 1977). We undertook this study to quantify the observed large differential preference occurring among accessions of black sagebrush and to determine the relationship between preference and monoterpenoids.

\section{Methods and Materials}

We selected 7 accessions of black sagebrush from a uniform garden located on the Gordon Creek Wildlife Management Area' near Helper, Utah for this study. The accessions had been transplanted as seedlings from various locatons (Table 1 ). This transplanting took place in the spring of 1969 ; plants under study were about 13 years old. The accessions were planted in rows. Placement of the rows of black sagebrush on the garden was random among 106 rows of other shrubs. Of the 106 rows, 11 were accessions of black sagebrush.

Approximately 200 to 300 mule deer winter in the area for 2 to 3 months. Winter consumption in the garden is due to mule deer and a very small population of black-tailed jackrabbits (Lepus californicus). Jackrabbit use on the garden was confined to grasses, forbs, rubber rabbitbrush (Chrysothamnus nauseosus), and an occasional big sagebrush plant. Mule deer distribution through the garden was even. In the spring, we could literally step from pellet group to pellet group across the depth and width of the garden. All

\footnotetext{
Authors are research associatc, Department of Range Sciences, Colorado Statc University, Fort Collins 80521; and principal plant physiologist, USDA Forest Service, Intermountain Forest and Range Experiment Station, Shrub Sciences Laboratory, 735 North 500 East, Provo. Utah 84601 .

Manuscript accepted October $15,1984$.
}

The shrub garden at the Gordon Creek Wildlife Management Area near Helper, Utah, is cooperatively maintained by the Utah Division of Wildlife Resources (Wildlife restoration funds W-82-R, job 1 ) and the Intermountain Forest and Range Experiment Station.
106 rows had deer tracks leading up and down the rows.

Preference was determined from 7 plants chosen at random among 30 to 40 plants and another set of 7 plants was randomly selected to determine monoterpenoid content for each accession. Because of lack of available plants, only 4 plants were used for monoterpenoid analysis for the Spring Valley and Wingate Mesa accessions. Samples from these 2 accessions were composited.

Table 1. Locations by county and state (landmark or town) where 7 accessions of black sagebrush (Artemisia nova) were collected.

\begin{tabular}{ll}
\hline \hline Accession & Location \\
\hline Black Mountain & Sevier, Utah (Salina) \\
Dove Creek & Dolores, Colorado (Dove Creek) \\
Manti & Sanpete, Utah (Manti) \\
Fremont Junction & Sevier, Utah (Fremont Jct.) \\
Wingate Mesa & San Juan County, Utah (Fry Canyon) \\
Spring Valley & White Pine, Nevada (Jct. US 93, 6, and S0) \\
Pine Valley Ridge & Millard, Utah (Desert Experimental Range) \\
\hline
\end{tabular}

A total of 15 annual leaders per plant were randomly selected and were measured to the nearest centimeter in November 1982. The 15 measurements per plant were used to calculate a mean annual leader length per plant before browsing. Plants were remeasured using 15 randomly selected leaders the following April, 1983. A mean annual leader length after browsing was calculated. Percentage use was calculated by dividing the mean leader length after browsing by the mean leader length before browsing, multiplying by 100 , and subtracting from 100 . Welch et al. (1981) reported a precision error of $4 \%$ for this method.

In December 1982, vegetative samples (current annual growthstems and leaves) from the 7 plants per accession were collected at random throughout the entire crown of the plants. These samples were used to determine monoterpenoid content. The early sampling date was necessary because use on the Pine Valley and Spring Valley accessions was so great that had we waited longer there would not have been any current annual growth with terminal buds left for analysis. The early sampling date placed $2 \mathrm{important}$ events close together: the selection of accessions by deer and the collection of forage tissue for monoterpenoid determinations. This is important because Cedarleaf et al. (1983) noticed significant changes in monoterpenoid concentrations over time. Samples collected from a plant were placed in a paper bag and frozen on site with dry ice. Later they were placed in plastic bags and stored at $-35^{\circ} \mathrm{C}$ to prevent monoterpenoid loss.

Samples were ground in a motorized mortar and pestle which was precooled with liquid nitrogen. Liquid nitrogen was also poured over the samples to prevent loss of monoterpenoids and to aid in grinding the samples to a fine powder. The methods used for extraction and analyzing for monoterpenoids have been described by Welch and McArthur (1981).

The resulting data were expressed as percentage utilized (preference) and percentage of monoterpenoids (dry matter basis). An analysis of variance (completely randomized design) was used to 
Table 3. Monoterpenoid content of 7 accessions of black sagebrush (Artemisia nova) grown on a uniform garden, and the relationship (5df, $P=0.05$, $\mathbf{r} \geq \mathbf{7 5 4}$ ) of content to wintering mule deer (Odocoileus hemionus hemionus) preference. Data expressed as a percentage of dry matter.

\begin{tabular}{|c|c|c|c|c|c|c|c|c|}
\hline \multirow[b]{2}{*}{ Accession } & \multicolumn{8}{|c|}{ Monoterpenoids } \\
\hline & $\alpha$-Pinene & Camphene & Carene & 1,8 Cineol & Cymol & Camphor & Terpineol & Total \\
\hline Black Mountain & 0.25 & 0.05 & 0.04 & 0.00 & 0.10 & 0.31 & 0.00 & 0.75 \\
\hline Dove Creek & 0.22 & 0.16 & 0.03 & 0.00 & 0.06 & 0.82 & 0.04 & 1.33 \\
\hline Manti & 0.34 & 0.02 & 0.03 & 0.00 & 0.04 & 0.26 & 0.01 & 0.70 \\
\hline Fremont Junction & 0.44 & 0.03 & 0.00 & 0.00 & 0.11 & 0.36 & 0.02 & $1.07 *$ \\
\hline Wingate Mesa & 0.30 & 0.03 & 0.00 & 0.00 & 0.01 & 0.36 & 0.00 & $1.02 *$ \\
\hline Spring Valley & 0.28 & 0.03 & 0.01 & 0.00 & 0.12 & 0.18 & 0.27 & $1.07^{*}$ \\
\hline Pine Valley Ridge & 0.15 & 0.05 & 0.00 & 0.03 & 0.00 & 0.38 & 0.02 & 0.63 \\
\hline r & -0.47 & -0.28 & -0.70 & +0.74 & -0.38 & -0.32 & +0.41 & -0.27 \\
\hline
\end{tabular}

-Total includes the concentration of unidentified monoterpenoids.

detect significant $(P<0.05)$ preference differences among the 7 accessions of black sagebrush. Student-Newman multiple range test was used to test for significant differences among accession means. Utilization percentages were transformed to arcsin to avoid inequalities (Snedecor and Cochran 1967). Correlation analysis was used to relate total and individual monoterpenoid content to preference.

\section{Results}

Wintering mule deer preferred some accessions of black sagebrush over others (Table 2). Black sagebrush from the Pine Valley

Table 2. Preference of wintering mule deer (Odocoileus hemionus hemionus) for 7 accessions of black sagebrush (Artemisia nova) grown on a uniform garden. Data expressed as percentage of current annual growth eaten.

\begin{tabular}{lc}
\hline Accession & Percent used \\
\hline Black Mountain & $0^{\mathrm{a}_{*}}$ \\
Dove Creek & $3.4^{\mathrm{a}}$ \\
Manti & $7.1^{\mathrm{a}}$ \\
Fremont Junction & $11.7^{\mathrm{a}}$ \\
Wingate Mesa & $40.6^{\mathrm{b}}$ \\
Spring Valley & $59.7^{\mathrm{c}}$ \\
Pine Valley Ridge & $82.7^{\mathrm{d}}$ \\
\hline
\end{tabular}

* Means sharing a common superscript are not different $(P<0.05)$.

Ridge area was the most preferred. Use among the accessions varied from 0 (Black Mountain) to $82.7 \%$ (Pine Valley Ridge) of the current year's growth. Differences were due to animal preferential browsing and not to uneven animal distribution because numbers of pellet groups within $1.2 \mathrm{~m}$ of the test plants were evenly distributed among the 7 accessions. Also, a row of big sagebrush just $1.2 \mathrm{~m}$ to the east of the Black Mountain row ( 0 use) received heavy use.

Total and individual monoterpenoid content for the 7 accessions of black sagebrush is given in Table 3. Total monoterpenoid content among accessions ranges from $0.63 \%$ to $1.33 \%$. Of the 7 identified monoterpenoids, camphor and $\alpha$-pinene were highest in concentration (across all accessions) at $0.38 \%$ and $0.28 \%$, respectively. The relationship ( $5 \mathrm{df}, \boldsymbol{P}=\mathbf{0 . 0 5}, r \geq .754$ ) between monoterpenoid and preference was not significant (Table 3 ).

\section{Discussion}

Results of differential preference among accessions of black sagebrush help to resolve conflicting statements in the literature. Smith (1950) observed that wintering mule deer preferred big sagebrush over black sagebrush. Sheehy and Winward (1981) made similar observations. However, Nagy and Tengerdy (1968) and Dietz and Nagy (1976) have stated that black sagebrush is preferred by wintering mule deer over big sagebrush. Both points of view are true. Our study, Scholl et al. (1977), and Stevens and
McArthur (1974) agree that black sagebrush varies greatly in the amount of use received by wintering mule deer and domestic sheep. Also, the ranking of the 7 accessions is in line with our observations made over the past 7 years.

Dietz and Nagy (1976), Nagy and Tengerdy (1968), and Schwartz et al. (1980) suggest that monoterpenoid content adversely affects preference. Our study does not support these findings. Scholl et al. (1977) and Welch et al. (1982) reported no significant relationships between monoterpenoids and preference of several taxa of sagebrush by mule deer. Also, Welch et al. (1983) reported that an accession of big sagebrush (Hobble Creek) received about the same use as the Pine Valley Ridge black sagebrush but contained 3.5 times more monoterpenoids and 2.7 times more camphor, an oxygenated monoterpenoid.

In summary, the accession of black sagebrush from Pine Valley Ridge was preferred by wintering mule deer over 6 other accessions but monoterpenoid content was not related to preference. We will be evaluating the Pine Valley Ridge accession for possible inclusion in the Soil Conservation Service Plant Material Development Program as a superior cultivar of black sagebrush.

\section{Literature Cited}

Cedarleaf, J.D., B.L. Welch, and J.D. Brotherson. 1983. Seasonal variation of monoterpenoids in big sagebrush [Artemisia tridentata]. J. Range Manage. 36:492-294.

Dietz, D.R., and J.G. Nagy. 1976. Mule deer nutrition and plant utilization. p. 71-78. In: G.W. Workman and J.B. Low (eds.). Mule deer decline in the West: a symposium. Coll. Natur. Resour., Utah Agr. Exp. Sta., Logan.

Nagy, J.G., and W.L. Regelin. 1977. Influence of plant volatile oils on feed selection by animals. XIlth Cong. of Game Biologists. 13:225-230.

Nagy, J.G., and R.P. Tengerdy. 1968. Antibacterial action of essential oils of Artemisia as an ecological factor. 11. Antibacterial action of volatile oils of Artemisia tridentata (big sagebrush) on bacteria from rumen of wild mule deer. Appl. Microbiol. 16:441-444.

Scholl, J.P., R.G. Kelsey, and F.Shafizadeh. 1977. Involvement of volatile compounds of Artemisia in browse preference by mule deer. Biochem. System and Ecol. 5:291-295.

Schwartz, C.C., W.L. Regelin, and J.G. Nagy. 1980. Deer preference for juniper forages and volatile oil treated foods. J. Wildl. Manage. 44:114120.

Sheehy, D.P., and A.H. Winward. 1981. Relative palatability of seven Artemisia taxa to mule deer and sheep. J. Range Manage. 34:397-399.

Smith, A.D. 1950. Sagebrush as winter feed for mule deer. J. Wildl. Manage. 14:285-289.

Snedecor, G.W., and W.G. Cochran. 1967. Statistical methods. The lowa State University Press. Ames, lowa.

Stevens, R., and E.D. McArthur. 1974. A simple field technique for identification of some sagebrush taxa. J. Range Manage. 27:325-326.

Welch, B.L., and E.D. McArthur. 1981. Variation of monoterpenoid content among subspecies and accessions of Artemisia tridentata grown in a uniform garden. J. Range Manage. 34:380-384.

Welch, B.L., E.D. McArthur, and J.N. Davis. 1981. Differential preference of wintering mule deer for accessions of big sagebrush and for black sagebrush. J. Range Manage. 34:409-411. 
Welch, B.L., E.D. McArthur, and J.N. Davis. 1983. Mule deer preference and monoterpenoids (essential oils). J. Range Manage. 36:485-487.
Welch, B.L., H. Narjisse, and E.D. McArthur. 1982. Artemisia tridentata monoterpenoids effect on ruminant digestion and forage selection. $p$. 73-86. In: N. Margaris, A. Koedam, and D. Vokou (eds.). Aromatic plants: basic and applied aspects. Martinus Nijhoff Publ., Boston. 